\title{
Genome-Guided Characterization of Ochrobactrum sp. POC9 Enhancing Sewage Sludge Utilization-Biotechnological Potential and Biosafety Considerations
}

\author{
Krzysztof Poszytek ${ }^{1}$, Joanna Karczewska-Golec ${ }^{1}$, Anna Ciok ${ }^{2}$, Przemyslaw Decewicz ${ }^{2}$, \\ Mikolaj Dziurzynski ${ }^{2}$, Adrian Gorecki ${ }^{2}$, Grazyna Jakusz ${ }^{1}$, Tomasz Krucon ${ }^{1}$, Pola Lomza ${ }^{1}$, \\ Krzysztof Romaniuk ${ }^{2}$, Michal Styczynski ${ }^{2}$, Zhendong Yang ${ }^{1}$, Lukasz Drewniak ${ }^{1}$ \\ and Lukasz Dziewit ${ }^{2, *}$ \\ 1 Laboratory of Environmental Pollution Analysis, Faculty of Biology, University of Warsaw, Miecznikowa 1, \\ 02-096 Warsaw, Poland; kposzytek@biol.uw.edu.pl (K.P.); karczewska@biol.uw.edu.pl (J.K.-G.); \\ grazyna.jakusz@biol.uw.edu.pl (G.J.); tkrucon@biol.uw.edu.pl (T.K.); pola.lomza@biol.uw.edu.pl (P.L.); \\ zyang@biol.uw.edu.pl (Z.Y.); ldrewniak@biol.uw.edu.pl (L.D.) \\ 2 Department of Bacterial Genetics, Institute of Microbiology, Faculty of Biology, University of Warsaw, \\ Miecznikowa 1, 02-096 Warsaw, Poland; aciok@biol.uw.edu.pl (A.C.); decewicz@biol.uw.edu.pl (P.D.); \\ mikolaj.dziurzynski@biol.uw.edu.pl (M.D.); agorecki@biol.uw.edu.pl (A.G.); \\ romaniuk@biol.uw.edu.pl (K.R.); mstyczynski@biol.uw.edu.pl (M.S.) \\ * Correspondence: ldziewit@biol.uw.edu.pl; Tel.: +48-225-541-406
}

Received: 21 June 2018; Accepted: 12 July 2018; Published: 16 July 2018

\begin{abstract}
Sewage sludge is an abundant source of microorganisms that are metabolically active against numerous contaminants, and thus possibly useful in environmental biotechnologies. However, amongst the sewage sludge isolates, pathogenic bacteria can potentially be found, and such isolates should therefore be carefully tested before their application. A novel bacterial strain, Ochrobactrum sp. POC9, was isolated from a sewage sludge sample collected from a wastewater treatment plant. The strain exhibited lipolytic, proteolytic, cellulolytic, and amylolytic activities, which supports its application in biodegradation of complex organic compounds. We demonstrated that bioaugmentation with this strain substantially improved the overall biogas production and methane content during anaerobic digestion of sewage sludge. The POC9 genome content analysis provided a deeper insight into the biotechnological potential of this bacterium and revealed that it is a metalotolerant and a biofilm-producing strain capable of utilizing various toxic compounds. The strain is resistant to rifampicin, chloramphenicol and $\beta$-lactams. The corresponding antibiotic resistance genes (including $b l_{\mathrm{OCH}}$ and $\mathrm{cmlA} / f l o R$ ) were identified in the POC9 genome. Nevertheless, as only few genes in the POC9 genome might be linked to pathogenicity, and none of those genes is a critical virulence factor found in severe pathogens, the strain appears safe for application in environmental biotechnologies.
\end{abstract}

Keywords: antibiotic resistance; biosafety; biogas production; Ochrobactrum sp. POC9; methane; sewage sludge utilization

\section{Introduction}

Natural and anthropogenically-shaped environments are frequently screened for the presence of bacterial strains potentially useful in environmental biotechnologies [1-4]. Municipal wastewaters and the products of their transformation (including sewage sludge)—as the environments rich in 
various toxic compounds-are potentially a good source of microorganisms metabolically active against numerous contaminants. Such microorganisms are well adapted to a variety of life-limiting factors, including toxic organic compounds and heavy metals [5-7], and thus are desired in technologies dedicated to sewage sludge transformation and utilization. However, pathogenic and antibiotic-resistant strains can also be found amongst bacteria isolated from wastewaters [8-10]. Therefore, for biosafety reasons, each isolate should be thoroughly analysed and, ideally, its genome should be explored to track, e.g., antibiotic resistance and virulence genes.

Ochrobactrum spp. are aerobic, non-fermenting, Gram-negative bacteria thriving in various environments, including soil, water, plants, and animals [11-15]. Members of the Ochrobactrum genus have frequently been isolated from environments persisting under strong anthropogenic pressure and some representatives were defined as animal and human pathogens. For example, $O$. anthropi and O. intermedium were recognized as relatively benign opportunistic human pathogens, infecting mostly immunocompromised patients [11,15-19]. However, cases of life-threatening infections, e.g., endocarditis caused by $O$. anthropi, were also reported [20]. Ochrobactrum spp. are metabolically versatile and exhibit some unique features, e.g., O. intermedium MZV101 is able to produce lipase and biosurfactants at $\mathrm{pH} 10$ and temperature of $60^{\circ} \mathrm{C}$ [21]. What is more, Ochrobactrum spp. seem to be well adapted for living in contaminated environments, which are rich in xenobiotics, organic pollutants and heavy metals. Ochrobactrum strains produce a variety of hydrolyzing enzymes that enable them to utilize even hardly-degradable compounds, e.g., phenols, organophosphorus pesticides and petroleum hydrocarbons [22-26]. Therefore, bacteria of this genus gained attention as promising candidates for use in diverse fields of biotechnology. They have been frequently employed in bioremediation technologies, e.g., in continuously stirred tank bioreactors to treat hydrocarbon-rich industrial wastewaters, or in biopiles and land farming to remove petroleum pollutions [27-30].

In this study, a novel Ochrobactrum strain, Ochrobactrum sp. POC9, was isolated from sewage sludge originated from the wastewater treatment plant (WWTP) "Czajka" in Warsaw, Poland. The strain exhibited various enzymatic activities, and significantly enhanced biogas production by improving sewage sludge utilization. The draft genomic sequence of Ochrobactrum sp. POC9 was obtained and thoroughly analyzed, which-together with functional analyses-provided insight into the biotechnological potential and the biosafety of the strain.

\section{Materials and Methods}

\subsection{Isolation of Ochrobactrum sp. POC9, Culture Conditions and Screening of Enzymatic Activities}

A raw sewage sludge sample collected from the wastewater treatment plant "Czajka" (Warsaw, Poland) was serially diluted using $0.8 \%(w / v)$ saline solution. Then, $100 \mu \mathrm{L}$ of each dilution was spread on lysogeny broth (LB) solidified by the addition of $1.5 \%(w / v)$ agar [31]. The plates were incubated at $37^{\circ} \mathrm{C}$ for $72 \mathrm{~h}$. A random selection of 100 isolates differing in their colony morphology was subjected to enzymatic activity examination. For testing of the proteolytic activity, Frazier agar (BTL, Lodz, Poland) and nutrient agar medium [31] with skim milk $(10 \% v / v)$ were used. For screening of the lipolytic activity, tributyrin agar (Sigma-Aldrich, St. Louis, MO, USA) was used. For screening of the cellulolytic and amylolytic activities, CMC-Red Congo agar [32] and nutrient agar medium [31] supplemented with a specific soluble chromogenic substrate (Megazyme, Bray, Ireland), respectively, were used. In each case, the material from a single colony was transferred onto the specific medium and the plates were incubated at $37^{\circ} \mathrm{C}$ for $72 \mathrm{~h}$, during which the visual observation was performed. Formation of clearing zones around the bacterial colonies indicated the hydrolysis of a particular substrate. Each experiment was carried out in triplicate. Based on the results of the performed analyses, the fastest growing strain (Ochrobactrium sp. POC9) exhibiting proteolytic, lipolytic, cellulolytic and amylolytic activities was selected for further studies. 


\subsection{Amplification and Sequencing of the $16 S$ rRNA Gene}

Genomic DNA was extracted from the bacterial cells using Genomic Mini purification kit (A\&A Biotechnology, Gdynia, Poland). The 16S rRNA gene fragment was amplified by PCR with universal primers $27 \mathrm{f}$ and $1492 \mathrm{r}$ [33]. The amplified $16 \mathrm{~S}$ rDNA fragment was used as a template for DNA sequencing with ABI3730xl DNA Analyzer (Applied Biosystems, Thermo Fisher Scientific, Foster City, CA, USA).

\subsection{Draft Genome Sequencing}

Genomic DNA of the POC9 strain was isolated using the CTAB/Lysozyme method [31]. An Illumina TruSeq library was constructed following the manufacturer's instructions. The genomic libraries were sequenced on Illumina MiSeq instrument (using the v3 chemistry kit) (Illumina, San Diego, CA, USA) in the DNA Sequencing and Oligonucleotide Synthesis Laboratory (oligo.pl) at the Institute of Biochemistry and Biophysics, Polish Academy of Sciences, Warsaw. The reads trimmed with CutAdapt v 1.9.1 [34] were further assembled using Newbler De Novo Assembler v3.0 (Roche, Basel, Switzerland).

\subsection{Bioinformatic Analyses}

The POC9 genome was automatically annotated using RAST [35] on PATRIC 3.5.11 [36] web service. Similarity searches were performed using BLAST programs [37] and Pfam database [38]. Metabolic features were identified applying KEGG database [39]. The COG numbers were assigned to each gene by local RPS-BLAST search against the COG database (last modified 22 January 2015) with 1e-5 e-value threshold by considering only the best BLAST hits [40]. Putative rRNA and tRNA sequences were identified using the Rfam [41], tRNAScan-SE [42] and ARAGORN programs [43]. To identify genetic determinants responsible for the heavy metal resistance phenotype, the genome was screened using the BacMet: antibacterial biocide and metal resistance genes database [44]. To identify antibiotic resistance genes, the Resistance Gene Identifier (RGI; Comprehensive Antibiotic Resistance Database) software was used [45]. Potential virulence factors were identified using VFDB-Virulence Factors Database [46].

\subsection{Analytical Methods}

Dry organic matter (VS) analysis was performed according to standard methods described by the American Public Health Association (APHA, 1998) [47]. The volatile fatty acids (VFAs) concentration and soluble chemical oxygen demand (sCOD) were determined using Nanocolor ${ }^{\circledR}$ kits (Machery-Nagel $\mathrm{GmbH}$, Düren, Germany). The volume of the produced biogas was monitored using Milligascounter MGC-1 (Ritter, Bochum, Germany). Methane content was analyzed with a gas analyzer GA5000 (Geotech, Leamington Spa, UK).

\subsection{Simulation of the Anaerobic Digestion Process}

The effect of bioaugmentation of sewage sludge anaerobic digestion with Ochrobactrum sp. POC9 was investigated in laboratory-scale anaerobic batch experiments, which were performed in 1-L glass bottles GL 45 (SCHOTT Poland, Warsaw, Poland) connected with Dreschel-type scrubbers. To each reactor, a 1-L Tedlar gas bag (Sigma-Aldrich, St. Louis, MO, USA) was attached to collect biogas. Each bioreactor was filled with (i) the liquid phase from a separated fermentation chamber from the wastewater treatment plant "Krym" (Wolomin, Poland) [11 g dry organic matter per $1\left(11 \mathrm{gvs} \cdot \mathrm{L}^{-1}\right)$ ], containing a methanogenic consortium inoculum and (ii) sewage sludge from the same WWTP [11 $\mathrm{g}$ dry organic matter per $1\left(11\right.$ gvs L$\left.\left.^{-1}\right)\right]$. Then, bioreactors were supplemented with $4 \mathrm{~mL}$ of the bacterial (Ochrobactrum sp. POC9) suspension (approx. $10^{7}$ cells $\cdot \mathrm{mL}^{-1}$ ). The negative controls for the experiment were cultures containing only methanogenic consortium and sewage sludge from the WWTP "Krym" without the addition of Ochrobactrum sp. POC9. At the beginning of the experiment, the total dry organic matter content in all bioreactors was $22 \mathrm{gvs} \cdot \mathrm{L}^{-1}$, soluble chemical oxygen demand (sCOD) was $1.97 \mathrm{~g} \mathrm{~L}^{-1}$ and VFAs concentration was $5.03 \mathrm{~g} \cdot \mathrm{L}^{-1}$. Anaerobic batch assays were run at 
$37^{\circ} \mathrm{C}$ for 30 days without refeeding. Analyses were carried out at the beginning of the experiment and after $3,7,14,21$, and 30 days. The experiment was performed in triplicate.

\subsection{Antibiotic Susceptibility Testing}

To determine the antimicrobial susceptibility patterns of Ochrobactrum sp. POC9, MICs of 10 antimicrobial agents were assessed using Etest ${ }^{\mathrm{TM}}$ (Liofilchem, Roseto degli Abruzzi, Italy). The analysis was conducted according to European Committee on Antimicrobial Susceptibility Testing (EUCAST) recommendations [48]. The following antibiotics (selected based on bioinformatic analyses that identified putative antibiotic resistance genes) were used: aminoglycosides-gentamicin $(\mathrm{CN}$; concentration of antibiotic: $0.064-1024 \mu \mathrm{g} \mathrm{mL}^{-1}$ ), $\beta$-lactams (penicillin derivatives)-ampicillin (AMP; $0.016-256 \mu \mathrm{g} \cdot \mathrm{mL}^{-1}$ ), $\beta$-lactams (cephalosporins)-cefixime (CFM; $0.016-256 \mu \mathrm{g} \cdot \mathrm{mL}^{-1}$ ), $\beta$-lactams (cephalosporins)-cefotaxime (CTX; 0.016-256 $\mu \mathrm{g} \cdot \mathrm{mL}^{-1}$ ), $\beta$-lactams (cephalosporins)-ceftriaxone (CRO; 0.016-256 $\mu \mathrm{g} \mathrm{mL} \mathrm{mL}^{-1}$ ), fluroquinolones- ciprofloxacin (CIP; $0.002-32 \mu \mathrm{g} \cdot \mathrm{mL}^{-1}$ ), fluroquinolones-moxifloxacin (MXF; 0.002-32 $\left.\mu \mathrm{g} \cdot \mathrm{mL}^{-1}\right)$, phenicols-chloramphenicol $\left(C ; 0.016-256 \mu \mathrm{g} \cdot \mathrm{mL}^{-1}\right)$, ryfamicins-rifampicin (RD; 0.016-256 $\mu \mathrm{g} \cdot \mathrm{mL}^{-1}$ ), tetracyclines-tetracycline (TE; 0.016-256 $\mu \mathrm{g} \cdot \mathrm{mL}^{-1}$ ). The susceptibility testing was performed at $37{ }^{\circ} \mathrm{C}$ for $20 \mathrm{~h}$. After incubation, plates were photographed and MICs were defined. Antimicrobial susceptibility data were interpreted according to the EUCAST breakpoint table (version 8.0) [48].

\subsection{Heavy Metal Resistance Testing}

Analytical grade salts $\left(\mathrm{NaAsO}_{2}, \mathrm{Na}_{2} \mathrm{HAsO}_{4} \times 7 \mathrm{H}_{2} \mathrm{O}, 3 \mathrm{CdSO}_{4} \times 8 \mathrm{H}_{2} \mathrm{O}, \mathrm{CoSO}_{4} \times 7 \mathrm{H}_{2} \mathrm{O}, \mathrm{K}_{2} \mathrm{CrO}_{4}\right.$, $\mathrm{CuSO}_{4}, \mathrm{NiSO}_{4} \times 7 \mathrm{H}_{2} \mathrm{O}, \mathrm{ZnSO}_{4} \times 7 \mathrm{H}_{2} \mathrm{O}$ ) (Sigma-Aldrich) were used in a resistance assay performed in 96-well plates, as described previously [49]. Triplicate cultures of the tested strain were challenged with a range of concentrations of those heavy metal salts. If the strain grew in the presence of the following heavy metal ion concentrations, it was considered resistant: (i) $10 \mathrm{mM}$ As (V), (ii) $1 \mathrm{mM}$ $\mathrm{Cd}^{2+}, \mathrm{Co}^{2+}, \mathrm{CrO}^{2-}, \mathrm{Cu}^{2+}, \mathrm{Ni}^{2+}, \mathrm{Zn}^{2+}$, (iii) $2.5 \mathrm{mM}$ As (III) [50-53].

\subsection{Adherence of Bacteria to Artificial Surface (Biofilm Formation) Testing}

The modified crystal violet staining method was used [54]. Bacteria were cultivated overnight in LB medium at $37^{\circ} \mathrm{C}$ and then diluted to obtain $\mathrm{OD}$ (optical density) $=0.1$ at $600 \mathrm{~nm}\left(\mathrm{OD}_{600}\right.$; $\mathrm{CFU} \approx 1.3 \times 10^{8}$ ) in the same medium. In the next step, $200 \mu \mathrm{L}$ of three biological replicates were transferred into 24 sterile 96-well plates. Bacteria were incubated at $37^{\circ} \mathrm{C}$ for $24 \mathrm{~h}, 48 \mathrm{~h}$, and $72 \mathrm{~h}$. The $\mathrm{OD}_{600}$ of cultures was then measured using Sunrise ${ }^{\mathrm{TM}}$ plate reader (Tecan, Männedorf, Switzerland) with Magellan software (Tecan). In the next step, the medium with pelagic cells (i.e., cells that did not adhere to artificial surface, and thus were not a part of a formed biofilm or alternatively were released from a formed biofilm) from each well was removed, and the wells were rinsed with saline solution and dried at $37^{\circ} \mathrm{C}$ for about $15 \mathrm{~min}$. The adhered (biofilm-forming) bacteria were stained with crystal violet ( $200 \mu \mathrm{L} /$ well) for $10 \mathrm{~min}$ at room temperature. Then, an excess dye was removed, wells were rinsed with saline solution, and dried again at $37^{\circ} \mathrm{C}$. Dried and stained biofilm was then dissolved with $98 \%$ ethanol $\left(200 \mu \mathrm{L} /\right.$ well). The OD $_{570}$ measurement of the obtained suspension was carried out using a Sunrise ${ }^{\mathrm{TM}}$ instrument equipped with Magellan software. The significance of statistical results was determined by the Student $t$-test [55].

\subsection{Nucleotide Sequence Accession Number}

The whole-genome shotgun project of Ochrobactrum sp. POC9 has been deposited in the NCBI GenBank (https://www.ncbi.nlm.nih.gov/genbank) database under the accession number SAMN09237519. 


\section{Results and Discussion}

\subsection{Isolation and Identification of Ochrobactrum sp. POC9}

Ochrobactrum sp. POC9 was isolated from raw sewage sludge collected from the "Czajka" wastewater treatment plant (Warsaw, Poland) in 2014. An initial screening for culturable bacteria was aimed at isolating strains capable of utilizing a broad spectrum of organic compounds. In such preliminary tests, the POC9 strain exhibited unequivocal lipolytic, proteolytic, cellulolytic, and amylolytic activities. For identification of this bacterium, its $16 \mathrm{~S}$ rRNA gene was amplified and sequenced. The obtained sequence was compared with the $16 \mathrm{~S}$ rDNA sequences gathered in the NCBI database, and the POC9 strain was classified into the Ochrobactrum genus.

A phylogenetic analysis based on 16S rDNA sequences of the POC9 strain and 20 other reference Ochrobactrum species was then performed. Analysis of the phylogenetic tree topology revealed the presence of two separate clusters. The first one gathered 12 species with the O. endophyticum EGI 60010 as an outlier. The second cluster grouped nine representatives of Ochrobactrum spp. with Ochrobactrum sp. POC9 as an outlier. Based on 16S rDNA sequence analysis results we may speculate that Ochrobactrum sp. POC9 is most closely related to O. intermedium and O. ciceri (Figure 1).

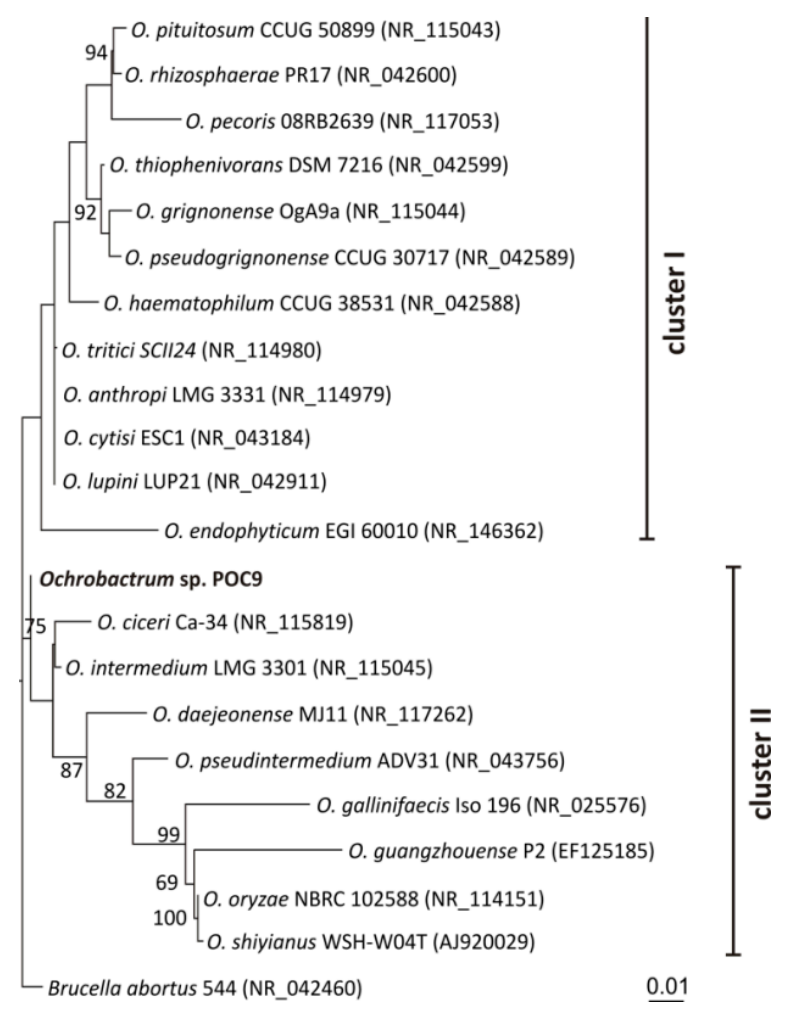

Figure 1. Phylogenetic tree for $16 \mathrm{~S}$ rDNA sequences of Ochrobactrum spp. The tree was constructed by applying the Maximum Likelihood method based on the Tamura-Nei model. Statistical support for the internal nodes was determined by 1000 bootstrap replicates and values of $\geq 50 \%$ are shown. Initial tree(s) for the heuristic search were obtained automatically by applying Neighbor-Join and BioNJ algorithms to a matrix of pairwise distances estimated using the Maximum Composite Likelihood (MCL) approach. A discrete Gamma distribution was used to model evolutionary rate differences among sites $(5$ categories $(+\mathrm{G}$, parameter $=0.6173)$ ). The tree is drawn to scale, with branch lengths measured in the number of substitutions per site. The analysis involved 22 nucleotide sequences with $16 \mathrm{~S}$ rDNA sequence of Brucella abortus 544 used as an outlier. All positions containing gaps and missing data were eliminated. There were a total of 1353 positions in the final dataset. GenBank accession numbers of the $16 \mathrm{~S}$ rDNA sequences used for the phylogenetic analysis are given in parentheses. The 16S rDNA of the POC9 strain, analyzed in this study, is in bold text. 


\subsection{Bioaugmentation of Sewage Sludge Anaerobic Digestion}

Bioaugmenation is a method that relies on adding specific microorganisms or microbial consortia to biological systems to enhance a desired activity [56]. This technology can be also applied in anaerobic digestions, e.g., to increase biogas (methane) production. Examples of various bioaugmentation procedures applied in anaerobic digestion of wastes are presented in Table 1.

Table 1. Examples of various bioaugmentation procedures applied in anaerobic digestion of wastes.

\begin{tabular}{|c|c|c|c|c|}
\hline $\begin{array}{c}\text { Strain/ } \\
\text { Microbial Consortium }\end{array}$ & Scale & $\begin{array}{c}\text { Substrate for Anaerobic } \\
\text { Digestion }\end{array}$ & Effect & Reference \\
\hline $\begin{array}{l}\text { Caldicellulosiruptor } \\
\text { saccharolyticus, } \\
\text { Enterobacter cloacae }\end{array}$ & Laboratory & $\begin{array}{l}\text { Waste water sludge, pig } \\
\text { manure slurry and dried } \\
\text { plant biomass from } \\
\text { Jerusalem artichoke }\end{array}$ & $\begin{array}{c}\text { Increased biogas } \\
\text { production of up to } \\
160-170 \%\end{array}$ & [57] \\
\hline $\begin{array}{c}\text { Caldicellulosiruptor } \\
\text { lactoaceticus 6A, } \\
\text { Dictyoglomus sp. B4a }\end{array}$ & $\begin{array}{c}\text { Laboratory } \\
\text { (batch experiments and } \\
\text { CSTR bioreactor) }\end{array}$ & Cattle manure & $\begin{array}{l}\text { Increased methane } \\
\text { yield of up to } 93 \%\end{array}$ & [58] \\
\hline $\begin{array}{c}\text { Hemicellulolytic } \\
\text { consortium immobilized } \\
\text { on activated zeolite }\end{array}$ & $\begin{array}{c}\text { Laboratory } \\
\text { (batch experiments and } \\
\text { CSTR bioreactor) }\end{array}$ & Xylan from birch wood & $\begin{array}{l}\text { Increased methane } \\
\text { yield of up to } 5 \%\end{array}$ & [59] \\
\hline $\begin{array}{l}\text { Clostridium thermocellum, } \\
\text { Melioribacter roseus }\end{array}$ & $\begin{array}{l}\text { Laboratory scale } \\
\text { (batch experiments and } \\
\text { CSTR bioreactor) }\end{array}$ & Wheat straw & $\begin{array}{l}\text { Increased methane } \\
\text { yield of up to } 34 \%\end{array}$ & [60] \\
\hline $\begin{array}{l}\text { Ruminococcus flavefaciens } \\
\text { 007C, Pseudobutyrivibrio } \\
\text { xylanivorans Mz5T, } \\
\text { Fibrobacter succinogenes } \\
\text { S85 and Clostridium } \\
\text { cellulovorans }\end{array}$ & Laboratory & Brewery spent grain & $\begin{array}{c}\text { Increased biogas } \\
\text { production of up to } \\
5-18 \%\end{array}$ & [61] \\
\hline $\begin{array}{c}\text { Methanoculleus bourgensis } \\
\text { MS2 }\end{array}$ & Laboratory & $\begin{array}{l}\text { Ammonia-rich substrates } \\
\text { (mixed pig and chicken } \\
\text { manure, slaughterhouse } \\
\text { residues, and food } \\
\text { industry waste) }\end{array}$ & $\begin{array}{l}\text { Increased methane } \\
\text { yield of up to } 34 \%\end{array}$ & [62] \\
\hline $\begin{array}{l}\text { Microbial consortium } \\
\text { with high cellulolytic } \\
\text { activity (MCHCA) }\end{array}$ & $\begin{array}{c}\text { Laboratory } \\
\text { (two-stage anaerobic } \\
\text { digestion) }\end{array}$ & $\begin{array}{c}\text { Maize silage } \\
\text { (lignocellulose biomass) }\end{array}$ & $\begin{array}{l}\text { Increased biogas } \\
\text { production of up to } \\
38 \% \text {, increased } \\
\text { methane yield of } \\
\text { up to } 64 \%\end{array}$ & [63] \\
\hline
\end{tabular}

Lipids, proteins and polysaccharides in sewage sludge are a potent source of energy and substrates for biogas production [64]. However, such use of sewage sludge is limited due to its heterogeneity, complex structure, and the presence of toxic compounds, e.g., heavy metals [65]. The initial breakdown of sewage sludge components can be substantially improved by the addition of bacteria capable of hydrolyzing complex compounds [66].

The POC9 strain exhibited diverse enzymatic (lipolytic, proteolytic, cellulolytic and amylolytic) activities under laboratory conditions. To determine whether the strain is able to break down complex residues present in sewage sludge, and thus whether it could be used for bioaugmentation of anaerobic digestion of sewage sludge, batch experiments were performed. The bioaugmentation with Ochrobactrum sp. POC9 was carried out once, at the beginning of the experiment. During a 30-day simulation of anaerobic digestion of sewage sludge, the daily biogas production yield and methane content in biogas were measured.

The cumulative biogas production in cultures supplemented with the POC9 strain increased by $22.06 \%$ compared to the control (non-bioaugmented) cultures. The cumulative biogas production for anaerobic digestion of sewage sludge with the addition of Ochrobactrum sp. POC9 was $294.58 \pm 44.98 \mathrm{dm}^{3} / \mathrm{kg}$ of VS, while in the control experiment it was $229.58 \pm 13.92 \mathrm{dm}^{3} / \mathrm{kg}$ (Table 2). 
Interestingly, the analysis of the daily biogas production revealed that the increased biogas production occurred mostly during the first eight days of culturing (Figure S1).

Table 2. Cumulative biogas production and methane content in biogas of control and POC9supplemented variants of the experiment simulating anaerobic digestion of sewage sludge.

\begin{tabular}{ccccccc}
\hline $\begin{array}{c}\text { Parameter } \\
\text { (unit) }\end{array}$ & \multicolumn{3}{c}{ Control } & \multicolumn{3}{c}{ Culture with the POC9 Strain } \\
\cline { 2 - 7 } & $\mathbf{3}$ days & $\mathbf{7}$ days & $\mathbf{3 0}$ days & $\mathbf{3}$ days & $\mathbf{7}$ days & $\mathbf{3 0}$ days \\
\hline $\begin{array}{c}\text { Cumulative biogas production }(\mathrm{L} / \mathrm{kgvs}) \\
\mathrm{CH}_{4} \text { content }(\%)\end{array}$ & \multicolumn{3}{c}{$229.58 \pm 13.92$} & & $294.58 \pm 44.98$ \\
\end{tabular}

The methane content during anaerobic digestion of sewage sludge after bioaugmentation with Ochrobactrum sp. POC9 increased from $46.00 \%$ in the third day of culturing to $58.87 \%$ after 30 days of culturing, and was highest on the seventh day- $66.48 \%$ (Table 2). At the same time, methane content in biogas in the control variant increased from $43.41 \%$ to $49.18 \%$, and was highest also on the seventh day, when it reached $61.34 \%$ (Table 2).

The results showed that the bioaugmentation with the POC9 strain improved the overall biogas production and methane content during anaerobic utilization of sewage sludge. This might be a consequence of improved hydrolysis occurring at the first stage of an anaerobic decomposition process. During this step, the combined lipolytic, proteolytic, cellulolytic and amylolytic activities of the POC9 strain probably enabled specific "pretreatment" of the raw sewage sludge, leading to increased production of easily utilizable, simple compounds (e.g., simple sugars, fatty acids, amino acids, etc.) that may be readily used by indigenous microorganisms (i.e., acetogenic bacteria and metahnogenic arachaea) for biogas production.

\subsection{Genome-Based Insight into the Metabolic Potential of the POC9 Strain}

Sequencing of the Ochrobactrum sp. POC9 genome on the Illumina MiSeq platform generated $1,275,451$ paired-reads and 76,6385,632 nucleotides. As the result of the assembly, 298 contigs of a total length of 4,976,112 bp were obtained. The genome sequence was automatically annotated using RAST on PATRIC 3.5.11 web service and its general features are presented in Table 3. Based on the results of the manual inspection of the genome assembly and annotation, three potential plasmid contigs: contig00029 (35,460 bp; QGST01000029.1), contig00037 (31,160 bp; QGST01000037.1), and contig00057 (5064 bp; QGST01000057.1) were identified. In these contigs, complete repABC-type replication-partitioning modules, typical of large replicons of Alphaproteobacteria, were found [67].

Table 3. General features of the Ochrobactrum sp. POC9 draft genome.

\begin{tabular}{cc}
\hline Genomic feature & Calculation \\
\hline Number of contigs & 298 \\
Estimated genome size (bp) & $4,976,112$ \\
GC content $(\%)$ & $55.68 \%$ \\
Coding density (\%) & $89.07 \%$ \\
Number of genes & 5217 \\
Number of tRNA genes & 66 \\
Number of 16S-23S-5S rRNA clusters & 3 \\
\hline
\end{tabular}

Genes identified within the POC9 genome were blasted against the COG database [40]. COG numbers were assigned to 3894 genes, considering only the best RPSBLAST hit with the e-value threshold of 1e-5. The genes were classified into appropriate COG categories (Figure 2).

This analysis revealed that 2005 (51.5\%) genes with assigned COG numbers were associated with the cellular metabolism, and the most numerous fractions of the classified genes were: E (grouping 
proteins associated with amino acid transport and metabolism) - $13.2 \%, \mathrm{G}$ (carbohydrate transport and metabolism) $-9.6 \%$, and P (inorganic ion transport and metabolism) $-7.7 \%$. These observations suggested that the POC9 strain possesses complex metabolic networks and is able to utilize or transform a broad spectrum of organic and inorganic compounds.

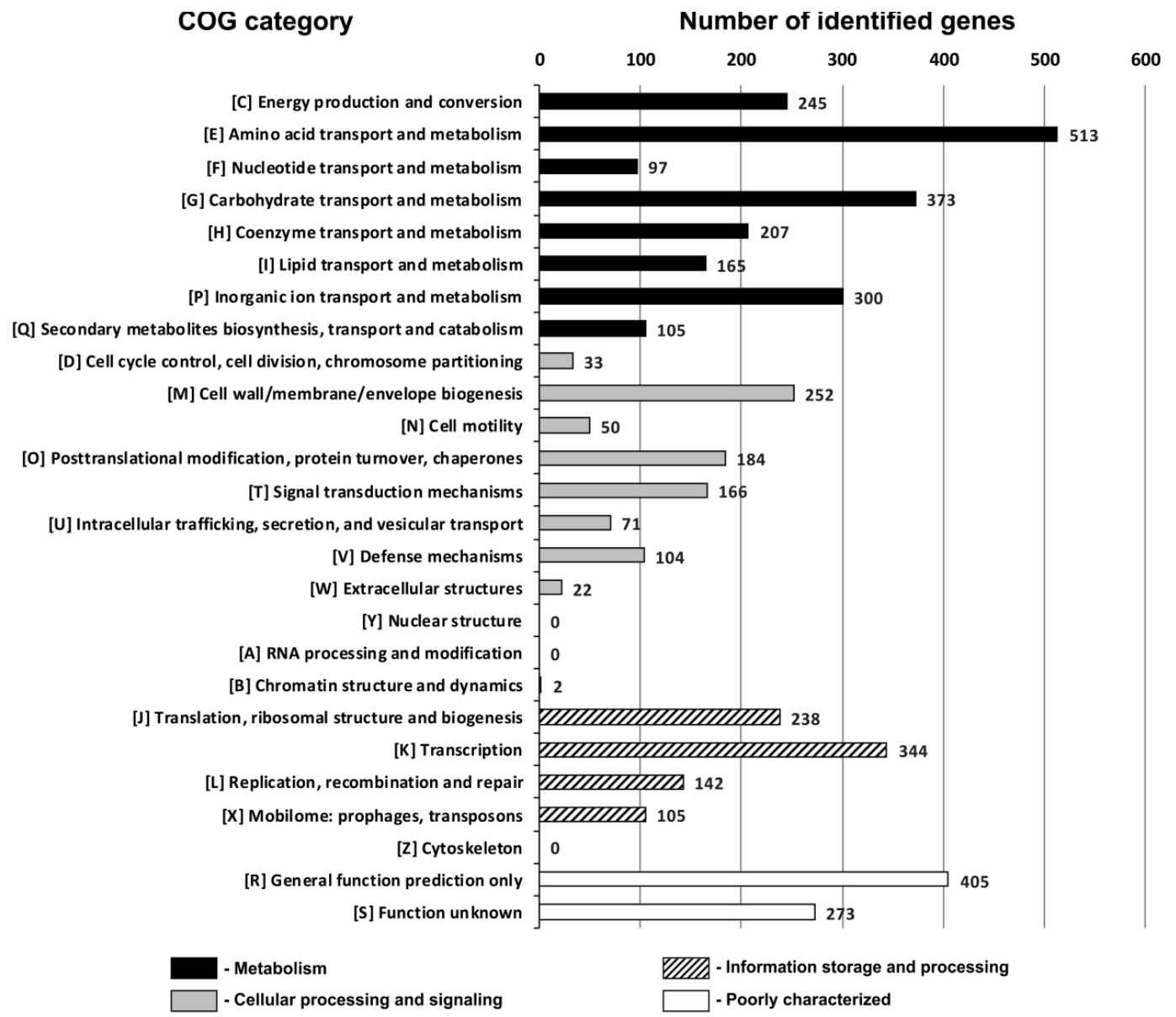

Figure 2. Number of genes classified into particular COG functional categories.

To gain a deeper insight into the POC9 metabolic potential, its draft genome was subjected to an analysis with KEGG Automatic Annotation System (KAAS), which allowed for reconstruction of its metabolic pathways. Apart from the basic metabolic pathways, such as glycolysis and the Krebs cycle, the KEGG-mapping revealed the presence of genes encoding both the enzymes enabling utilization of complex and toxic compounds and other features important in biotechnological applications, and especially advantageous in sewage sludge utilization. Ochrobactrum sp. POC9 possesses complete gene repertoires for the following pathways: (i) phenol degradation through benzoate utilization [23], (ii) propanoate utilization [68], (iii) denitrification [69], and (iv) assimilatory sulfate reduction [70] (Figure S2). Given the potential application of Ochrobactrum sp. POC9 for enhanced biogas production, it is also important to emphasize its possible contribution to $\mathrm{CO}_{2}$ availability for methanogenesis. The POC9 strain can potentially produce $\mathrm{CO}_{2}$ in the citric acid cycle and also through decarboxylation of formate, formaldehyde, and $N$-formyl derivatives [71,72] (Figure S2).

\subsection{Heavy Metal Metabolism}

We demonstrated that Ochrobactrum sp. POC9 enhances sewage sludge utilization. However, sewage sludge usually contains various toxic contaminants, including heavy metals and metalloids (e.g., As, Cd, Co, Cr, Cu, Fe, Hg, Ni, Pb and Zn) [73-75]. The presence of such toxic compounds may decrease 
the overall efficiency of the utilization treatment due to their bactericidal effect on the exogenous microorganisms used in the treatment. Hence, bacterial strains used in bioaugmentation during sewage sludge utilization should tolerate heavy metals at the highest possible concentrations [76].

Therefore, in the next step, the POC9 genome was screened for the presence of genes putatively involved in heavy metal ions transformation and resistance. We found 10 such genetic modules, encoding: (i-vi) six heavy metal translocating P-type ATPases ZntA (COG2217), which may potentially confer resistance to various divalent ions, i.e., $\mathrm{Cd}(\mathrm{II}), \mathrm{Co}(\mathrm{II}), \mathrm{Cu}(\mathrm{II}), \mathrm{Ni}(\mathrm{II}), \mathrm{Pb}$ (II), and $\mathrm{Zn}$ (II) [77-79]; (vii) chromate transport protein ChrA (COG2059), which actively transports chromate ions across cell membrane [80]; (viii-ix) two divalent metal ion transporters of the cation diffusion facilitator (CDF) family, i.e., FieF (COG0053), which usually function as Fe(II) efflux system but may also confer resistance to $\mathrm{Cd}(\mathrm{II}), \mathrm{Co}(\mathrm{II}), \mathrm{Ni}(\mathrm{II})$, and $\mathrm{Zn}(\mathrm{II})$, as well as $\mathrm{CzcD}$ (COG1230), which protects the cell from $\mathrm{Cd}(\mathrm{II}), \mathrm{Co}(\mathrm{II})$, and $\mathrm{Zn}(\mathrm{II})$ [81,82]; and (x) arsenic resistance module (ARS), which may be involved in resistance to arsenate and arsenite (Table 4). The ARS module encodes (i) arsenite efflux pump ArsB (COG0798) transporting As(III) ions out of the cell, (ii) arsenate reductase ArsC (COG1393), which reduces $\mathrm{As}(\mathrm{V})$ to $\mathrm{As}(\mathrm{III})$, and (iii) $\mathrm{ArsH}$, the function of which is not completely understood, but it was hypothesized that the protein may play a regulatory role [83].

Table 4. Heavy metal resistance genes identified within the Ochrobactrum sp. POC9 draft genome.

\begin{tabular}{|c|c|c|c|}
\hline $\begin{array}{l}\text { Protein } \\
\text { Name }\end{array}$ & $\begin{array}{l}\text { Localization within the POC9 Draft } \\
\text { Genome Sequence (GenBank acc. no.) }\end{array}$ & $\begin{array}{l}\text { Predicted Protein } \\
\text { Function }\end{array}$ & $\begin{array}{l}\text { Homologous Protein Based on Best } \\
\text { BLASTP Hit (GenBank acc. no.) }\end{array}$ \\
\hline $\operatorname{ars} B$ & $\begin{array}{l}\text { contig00008 (QGST01000008.1) } \\
\text { coordinates: } 148,637-147,576\end{array}$ & Export of As(III) ions & $\begin{array}{l}\text { arsenic transporter of O. anthropi } \\
\text { FRAF13 (KXO76567) }\end{array}$ \\
\hline $\operatorname{ars} C$ & $\begin{array}{l}\text { contig00008 (QGST01000008.1) } \\
\text { coordinates: } 147,579-147,169\end{array}$ & $\begin{array}{l}\text { Reduction of } \mathrm{As}(\mathrm{V}) \\
\text { to } \mathrm{As}(\mathrm{III})\end{array}$ & $\begin{array}{l}\text { arsenate reductase of O. intermedium } \\
\text { LMG } 3301 \text { (EEQ95705) }\end{array}$ \\
\hline $\operatorname{chr} A$ & $\begin{array}{l}\text { contig00005 (QGST01000005.1) } \\
\text { coordinates: } 67,497-66,199\end{array}$ & Export of $\mathrm{Cr}(\mathrm{VI})$ & $\begin{array}{c}\text { chromate transporter of Ochrobactrum } \\
\text { sp. EGD-AQ16 (ERI13917) }\end{array}$ \\
\hline$c z c D$ & $\begin{array}{l}\text { contig00031 (QGST01000031.1) } \\
\text { coordinates: } 6786-7745\end{array}$ & $\begin{array}{l}\text { Export of } \mathrm{Cd}(\mathrm{II}) \text {, } \\
\mathrm{Co}(\mathrm{II}) \text {, and } \mathrm{Zn}(\mathrm{II})\end{array}$ & $\begin{array}{l}\text { cation transporter of Ochrobactrum sp. } \\
\text { MYb71 (PQZ25943) }\end{array}$ \\
\hline$z n t A$ & $\begin{array}{l}\text { contig00025 (QGST01000025.1) } \\
\text { coordinates: } 28,104-26,260\end{array}$ & $\begin{array}{l}\text { Export of } \mathrm{Cd}(\mathrm{II}), \\
\mathrm{Co}(\mathrm{II}), \mathrm{Cu}(\mathrm{II}), \mathrm{Ni}(\mathrm{II}), \\
\mathrm{Pb}(\mathrm{II}), \text { and } \mathrm{Zn}(\mathrm{II})\end{array}$ & $\begin{array}{l}\text { haloacid dehalogenase of O. anthropi } \\
\text { FRAF13 (KXO73917) }\end{array}$ \\
\hline$z n t A$ & $\begin{array}{l}\text { contig00032 (QGST01000032.1) } \\
\text { coordinates: } 21,766-24,129\end{array}$ & $\begin{array}{l}\text { Export of } \mathrm{Cd}(\mathrm{II}), \\
\mathrm{Co}(\mathrm{II}), \mathrm{Cu}(\mathrm{II}), \mathrm{Ni}(\mathrm{II}), \\
\mathrm{Pb}(\mathrm{II}), \text { and } \mathrm{Zn}(\mathrm{II})\end{array}$ & $\begin{array}{l}\text { lead, cadmium, zinc and mercury } \\
\text { transporting ATPase; } \\
\text { copper-translocating P-type ATPase of } \\
\text { O. haematophilum FI11154 (SPL62610) }\end{array}$ \\
\hline$z n t A$ & $\begin{array}{l}\text { contig00034 (QGST01000034.1) } \\
\text { coordinates: } 5822-7666\end{array}$ & $\begin{array}{c}\text { Export of } \mathrm{Cd}(\mathrm{II}), \\
\mathrm{Co}(\mathrm{II}), \mathrm{Cu}(\mathrm{II}), \mathrm{Ni}(\mathrm{II}), \\
\mathrm{Pb}(\mathrm{II}), \text { and } \mathrm{Zn}(\mathrm{II})\end{array}$ & $\begin{array}{c}\text { cadmium-translocating P-type } \\
\text { ATPase of O. rhizosphaerae PR17 } \\
\text { (OYR19288) }\end{array}$ \\
\hline$z n t A$ & $\begin{array}{l}\text { contig00004 (QGST01000004.1) } \\
\text { coordinates: 22,193-19,692 }\end{array}$ & $\begin{array}{c}\text { Export of } \mathrm{Cd}(\mathrm{II}), \\
\mathrm{Co}(\mathrm{II}), \mathrm{Cu}(\mathrm{II}), \mathrm{Ni}(\mathrm{II}), \\
\mathrm{Pb}(\mathrm{II}), \text { and } \mathrm{Zn}(\mathrm{II})\end{array}$ & $\begin{array}{l}\text { copper-translocating P-type ATPase } \\
\text { of O. lupini LUP21 (OYR29555) }\end{array}$ \\
\hline
\end{tabular}


We tested whether the predicted genes and gene clusters identified in the POC9 genome are able to confer resistance to heavy metals. The effect of $\mathrm{As}(\mathrm{III}), \mathrm{As}(\mathrm{V}), \mathrm{Cd}(\mathrm{II}), \mathrm{Co}(\mathrm{II}), \mathrm{Cr}(\mathrm{VI}), \mathrm{Cu}(\mathrm{II}), \mathrm{Ni}(\mathrm{II})$, and $\mathrm{Zn}$ (II) ions on Ochrobactrum sp. POC9 growth was examined. These metals were selected based on the predicted metal specificity of the putative resistance genes identified within the POC9 genome (Table 4). The MIC values were determined to establish the levels of metal resistance of the strain. The obtained results are as follows: As(III)-MIC value of $3 \mathrm{mM}, \mathrm{As}(\mathrm{V})-1200 \mathrm{mM}, \mathrm{Cd}(\mathrm{II})-1 \mathrm{mM}$, $\mathrm{Co}(\mathrm{II})-1 \mathrm{mM}, \mathrm{Cr}(\mathrm{VI})-3 \mathrm{mM}, \mathrm{Cu}(\mathrm{II})-5 \mathrm{mM}, \mathrm{Ni}(\mathrm{II})-2 \mathrm{mM}$, and $\mathrm{Zn}$ (II) $-3 \mathrm{mM}$.

Ochrobactrum sp. POC9 exhibited an extremely high-level of $\mathrm{As}(\mathrm{V})$ resistance and a moderate level of As(III) resistance. The observed resistance to arsenic compounds is probably mediated by the presence of the ARS module enabling reduction of arsenate to arsenite and its further extrusion from the cell. The POC9 strain showed also a moderate level of resistance to $\mathrm{Cr}(\mathrm{VI}), \mathrm{Cu}(\mathrm{II}), \mathrm{Ni}(\mathrm{II})$, and $\mathrm{Zn}$ (II) ions, which may be linked to the presence of the above mentioned transporters of broad-range specificities, i.e., $\mathrm{ChrA}, \mathrm{CzcD}$, FieF, and ZntA.

The results indicated that the POC9 strain shows at least moderate resistance to six heavy metal ions that are frequently present in sewage sludge. This makes it a robust candidate for application in biotreatment of metal-contaminated waste, as the strain is well equipped to withstand the toxic effect of heavy metals in these environments.

\subsection{Antibiotic Resistance Genes and Virulence Factors}

Wastewater treatment plants are considered a point source of emerging pollutants, including antibiotics, antibiotic resistant and/or pathogenic bacteria as well as antibiotic resistance and virulence genes [84]. Therefore, with an aim to apply Ochrobactrum sp. POC9-a wastewater isolate-in biotechnology, and taking into account biosafety considerations, genome of this strain was analyzed for the presence of antibiotic resistance and virulence genes.

To determine the antimicrobial resistance profile of Ochrobactrum sp. POC9, bioinformatic analyses and MIC characterization using Etests were performed. It total, five antibiotic resistance genes $\left(b a_{\mathrm{OCH}}\right.$, $q a c H, c m l A / f l o R, a c c\left(6^{\prime}\right)$, and $\left.t e t G\right)$ and two clusters of genes encoding a multidrug efflux system (acrAB-TolC) potentially conferring resistance to various types of $\beta$-lactams, aminoglycosides, fluoroquinolones, tetracyclines, phenicols and ryfamicins were identified within the POC9 genome (Table 5).

Results of the analysis with Etests indicated that Ochrobactrum sp. POC9 is resistant to various $\beta$-lactams (including ampicillin, cefexime, cefotaxime, and ceftriaxone), rifampicin and chloramphenicol (Table 5). Broad spectrum resistance to various classes of $\beta$-lactams was previously observed in other (also non-pathogenic) Ochrobactrum strains [85]. Resistance phenotype in those strains was linked to the presence of a class $C \beta$-lactamase gene $\left(b l_{\mathrm{OCH}}\right)$ and to an upstream gene encoding a LysR family regulator [85]. Within the POC9 genome, the $b l a_{\mathrm{OCH}}$ gene and an upstream regulatory gcv $A$ gene were also found. Interestingly, protein products of these genes in POC9 exhibited 98\% sequence identity with class C beta-lactamase of Ochrobactrum tritci (GenBank acc. no. SME85995) and transcriptional regulator GcvA of Ochrobactrum anthropi (GeneBank acc. no. WP_061347328). It seems that the presence of highly conserved $b l a_{\mathrm{OCH}}$ gene is common in Ochrobactrum genomes. Furthermore, the POC9 strain was also resistant to chloramphenicol, which well reflects the presence of the $c m l A / f l o R$ gene in its genome [86].

The Etest results revealed that the POC9 strain was susceptible to ciprofloxacin, moxifloxacin, gentamicin and tetracycline, which suggests that $q a c H, a c c\left(6^{\prime}\right)$ and $\operatorname{tet} G$ were inactive under the tested laboratory conditions (Table 5). Further analyses with a broader range of antibiotics belonging to fluoroquinolones, aminoglycosides and tetracyclines should be carried out to test whether these genes are specific to other antibiotics of these groups.

The results of the susceptibility testing did not enable us to unequivocally determine whether the above mentioned $a c r A B$-TolC modules encoding resistance-nodulation-cell division (RND) type multidrug efflux systems are active or not, as their predicted activities partially overlap with the specificities of proteins encoded by bla $a_{\mathrm{OCH}}$ and $c m l A / f l o R$ genes [85-87] (Table 5). 
Table 5. Antibiotic resistance genes identified within the Ochrobactrum sp. POC9 draft genome and the resistance profile of the strain.

\begin{tabular}{|c|c|c|c|c|c|c|}
\hline $\begin{array}{c}\text { Gene/Gene } \\
\text { Cluster } \\
\text { Name }\end{array}$ & $\begin{array}{l}\text { Localization within } \\
\text { the POC9 Draft } \\
\text { Genome Sequence } \\
\text { (GenBank acc. no.) }\end{array}$ & Protein & $\begin{array}{c}\text { Best BLAST Hits: } \\
\text { [\% Identity] } \\
\text { Organism } \\
\text { (GeneBank acc. no.) }\end{array}$ & $\begin{array}{c}\text { Predicted } \\
\text { Antimicrobial } \\
\text { Resistance Profile }\end{array}$ & $\begin{array}{c}\text { Tested } \\
\text { Antibiotics }\end{array}$ & Profile \\
\hline $\begin{array}{l}\text { gcvA- } \\
\text { bla }_{\mathrm{OCH}}\end{array}$ & $\begin{array}{c}\text { contig00009 } \\
\text { (QGST01000009.1) } \\
\text { coordinates: } \\
\text { 164,062-165,431 }\end{array}$ & $\begin{array}{l}\text { class } C \\
\text { beta-lactamase } \\
\text { transcriptional } \\
\text { regulator GcvA }\end{array}$ & $\begin{array}{c}\text { [98\%] Ochrobactrum } \\
\text { tritici C8846-N36 } \\
\text { (SME85995) } \\
\text { [98\%] Ochrobactrum } \\
\text { anthropi } \\
\text { (WP_061347328) }\end{array}$ & $\begin{array}{l}\text { penams, penems, } \\
\text { cephalosporins, } \\
\text { cephamycins, } \\
\text { monobactams }\end{array}$ & $\begin{array}{l}\text { AMP } \\
\text { CFM } \\
\text { CTX } \\
\text { CRO }\end{array}$ & $\begin{array}{l}\mathrm{R} \\
\mathrm{R} \\
\mathrm{R} \\
\mathrm{R}\end{array}$ \\
\hline $\begin{array}{l}\text { acr } A B- \\
\text { TolC }\end{array}$ & $\begin{array}{c}\text { contig00001 } \\
\text { (QGST01000001.1) } \\
\text { coordinates: } \\
191,438-196,605\end{array}$ & $\begin{array}{l}\text { transcriptional } \\
\text { regulator TetR } \\
\text { efflux RND } \\
\text { transporter } \\
\text { periplasmic } \\
\text { adaptor subunit } \\
\text { efflux RND } \\
\text { transporter } \\
\text { permease subunit }\end{array}$ & $\begin{array}{c}\text { [93\%] Ochrobactrum } \\
\text { oryzae } \\
\text { (WP_104756164) } \\
\text { [98\%] Ochrobactrum } \\
\text { anthropi } \\
\text { (WP_061344971) } \\
\text { [99\%] Ochrobactrum } \\
\text { anthropi } \\
\text { (WP_061344972) }\end{array}$ & \multirow[t]{2}{*}{$\begin{array}{c}\text { tetracyclines, } \\
\text { cephalosporins } \\
\text { penams, } \\
\text { phenicols, } \\
\text { ryfamycins, } \\
\text { fluoroquinolones }\end{array}$} & \multirow[t]{2}{*}{$\begin{array}{c}\text { AMP } \\
\text { CIP } \\
\text { CFM } \\
\text { CTX } \\
\text { CRO } \\
\text { TE } \\
\text { MXF } \\
\text { RIF }\end{array}$} & \multirow[t]{2}{*}{$\begin{array}{l}\mathrm{R} \\
\mathrm{S} \\
\mathrm{R} \\
\mathrm{R} \\
\mathrm{R} \\
\mathrm{S} \\
\mathrm{S} \\
\mathrm{R}\end{array}$} \\
\hline $\begin{array}{l}\text { acrAB- } \\
\text { TolC }\end{array}$ & $\begin{array}{c}\text { contig00010 } \\
\text { (QGST01000010.1) } \\
\text { coordinates: } \\
49,666-54,163\end{array}$ & $\begin{array}{l}\text { efflux RND } \\
\text { transporter } \\
\text { periplasmic } \\
\text { adaptor unit } \\
\text { efflux RND } \\
\text { transporter } \\
\text { permease subunit }\end{array}$ & $\begin{array}{c}\text { [98\%] Ochrobactrum } \\
\text { sp. (WP_024900215) } \\
\text { [99\%] Ochrobactrum } \\
\text { oryzae } \\
\text { (WP_104755654) }\end{array}$ & & & \\
\hline$q a c H$ & $\begin{array}{c}\text { contig00007 } \\
\text { (QGST01000007.1) } \\
\text { coordinates: } \\
\text { 192,104-191,772 }\end{array}$ & $\begin{array}{l}\text { efflux SMR } \\
\text { transporter }\end{array}$ & $\begin{array}{l}\text { [100\%] Ochrobactrum } \\
\text { sp. (WP_010661279) }\end{array}$ & fluoroquinolones & $\begin{array}{l}\text { CIP } \\
\text { MXF }\end{array}$ & $\begin{array}{l}S \\
S\end{array}$ \\
\hline cmlA/floR & $\begin{array}{c}\text { contig00016 } \\
\text { (QGST01000016.1) } \\
\text { coordinates: } \\
56,907-55,714\end{array}$ & $\begin{array}{c}\text { CmlA/floR } \\
\text { chloramphenicol } \\
\text { efflux MFS } \\
\text { transporter }\end{array}$ & $\begin{array}{c}\text { [94\%] Ochrobactrum } \\
\text { anthropi } \\
\text { (WP_061345584) }\end{array}$ & chloramphenicol & C & $\mathrm{R}$ \\
\hline $\operatorname{acc}\left(6^{\prime}\right)$ & $\begin{array}{c}\text { contig00016 } \\
\text { (QGST01000016.1) } \\
\text { coordinates: } \\
\text { 92,931-92,485 }\end{array}$ & $\begin{array}{c}\text { aminoglycoside } \\
\text { 6'-acetyl-transferase }\end{array}$ & $\begin{array}{c}\text { [93\%] Ochrobactrum } \\
\text { anthropi } \\
\text { FRAF13(KXO77791) }\end{array}$ & aminoglycosides & $\mathrm{CN}$ & $\mathrm{S}$ \\
\hline $\begin{array}{l}\text { tet } G- \\
\text { tetR }\end{array}$ & $\begin{array}{c}\text { contig00014 } \\
\text { (QGST01000014.1) } \\
\text { coordinates: } \\
\text { 7148-9063 }\end{array}$ & $\begin{array}{l}\text { Tet(A/B/C) } \\
\text { family MFS } \\
\text { transporter } \\
\text { transcriptional } \\
\text { regulator tetR }\end{array}$ & $\begin{array}{c}\text { [87\%] Ochrobactrum } \\
\text { oryzae } \\
\text { (WP_104755825) } \\
\text { [89\%] Ochrobactrum } \\
\text { oryzae } \\
\text { (WP_104755986) }\end{array}$ & tetracyclines & TE & S \\
\hline
\end{tabular}

Abbreviations: AMP-ampicillin; C—chloramphenicol; CN—gentamicin; CFM-cefixime; CTX-cefotaxime, CRO-ceftriaxone; CIP-ciprofloxacin; TE-tetracycline; MXF-moxifloxacin; RIF-rifampicin; R-resistant; S-susceptible.

The POC9 genome was also screened for the presence of putative virulence genes. Only a few genetic modules that may potentially be linked to pathogenicity were found. These were: (i-iii) Sec-SRP (the general secretion route), Tat (Twin-arginine translocation pathway), Vir-like type IV secretion systems (T4SS) [88], and (iv-v) genes responsible for the synthesis of flagella and sigma-fimbriae subsystem (sF-Chap, sF-UshP, sF-Adh), which may be responsible for biofilm formation and adherence of cells to various surfaces [89]. Within the genome of Ochrobactrum sp. POC9, we also identified several genes encoding proteins responsible for the synthesis of lipopolysaccharides (LpxA, LpxB, LpxC, LpxD, LpxH, LpxK, LpxL and KdtA) as well as ABC-type systems ( $r f b$ and $l p t)$ responsible for the transport of lipopolysaccharides [90-92]. Whereas these genes may be somehow linked to the POC9 strain pathogenicity, they are common among Alphaproteobacteria, including non-pathogenic strains [93]. 
The presence of genes involved in the synthesis of lipopolysaccharides constituting biofilm matrix as well as several genes that may indirectly influence biofilm formation (e.g., sigma-fimbriae subsystem) inspired us to analyze biofilm formation ability in the POC9 strain. Whereas bacterial biofilms are usually linked to the virulence of clinical strains, they also play a major ecological role in maintaining complex multispecies ecosystems in diverse environments [94]. Moreover, biofilms are also beneficial in bioremediation, e.g., they are crucial for the proper functioning of the attached growth systems in WWTPs [95]. The crystal violet staining method was applied to determine the adherence potential of Ochrobactrum sp. POC9. The results showed that the POC9 strain is able to adhere to surface after $24 \mathrm{~h}$ of incubation without shaking and then maintains the biofilm up to $48 \mathrm{~h}$ of incubation. Interestingly, after $72 \mathrm{~h}$, the biofilm began to disperse, resulting in a significant $(p<0.005)$ reduction of the adhered biomass (Figure S3). This observation suggested that the POC9 strain is able to form biofilm or to at least initiate its formation by adhesion to artificial surfaces. However, stable maintenance of the biofilm may require specific (and not yet recognized) environmental conditions or cooperation with other microorganisms.

\section{Conclusions}

In this study, a novel bacterial strain, Ochrobactrum sp. POC9, was isolated from sewage sludge. The strain exhibited diverse enzymatic (lipolytic, proteolytic, cellulolytic and amylolytic) activities, which suggested that it might be beneficial in the biodegradation of complex organic compounds. Therefore, the strain was tested for its ability to enhance the process of sewage sludge utilization, and was found to substantially improve the overall biogas yield and methane content during anaerobic digestion of sewage sludge. This may be a consequence of enhanced hydrolysis occurring at the first stage of the process. The obtained results suggest that Ochrobactrum sp. POC9 carries out specific "pretreatment" of the raw sewage sludge, which leads to increased production of easily utilizable simple organic compounds for other microorganisms (i.e., acetogenic bacteria and methanogenic arachaea) involved in the biogas production.

The analysis of the POC9 genome content offered a deeper insight into the biotechnological potential of this bacterium and revealed its denitrifying, biofilm forming, and toxic compound (e.g., phenol) utilization abilities. Genomic investigations combined with physiological analyses indicated also that Ochrobactrum sp. POC9 is a metalotolerant bacterium, and carries several heavy metal resistance genes in its genome. This is a beneficial feature, as heavy metals are common in wastes, and may generate bactericidal effect. We also demonstrated that the POC9 strain is resistant to various $\beta$-lactams (including ampicillin, cefexime, cefotaxime, and ceftriaxone), rifampicin and chloramphenicol, which well correlates with the presence of several antibiotic resistance genes, including bla $_{\mathrm{OCH}}$ and $\mathrm{cmlA} /$ floR, in the Ochrobactrum POC9 genome. Nevertheless, as only few genes in the POC9 genome were recognized as potentially linked to pathogenicity, and none of these genes is a critical virulence factor found in severe pathogens, the strain appears safe for environmental biotechnology applications.

\section{Patents}

Polish patent No. PL413998. Drewniak L., Poszytek K., Dziewit L., Sklodowska A. 2018. Consortium of microorganisms capable of hydrolysis of the proteins and lipids in the sewage sludge and/or contaminated soil, the formulation comprising them, the application of the consortium and method of hydrolysis of proteins, lipids and hardly degradable compounds in sewage sludge and/or organic compounds in soils.

Supplementary Materials: The following are available online at http:/ / www.mdpi.com/1660-4601/15/7/1501/ s1, Figure S1: Daily biogas production during anaerobic digestion of sewage sludge. Figure S2: Metabolic pathways of a putative biotechnological value recognized within the POC9 draft genome. Figure S3: Adherence of Ochrobactrum sp. POC9 to an artificial (plastic) surface after three time intervals ( $24 \mathrm{~h}, 48 \mathrm{~h}$ and $72 \mathrm{~h}$ ). 
Author Contributions: Conceptualization, K.P., L.D. (Lukasz Drewniak) and L.D. (Lukasz Dziewit); Methodology, K.P., L.D. (Lukasz Drewniak) and L.D. (Lukasz Dziewit); Software, P.D. and M.D.; Validation, K.P., J.K.-G., L.D. (Lukasz Drewniak) and L.D. (Lukasz Dziewit); Formal Analysis, K.P., J.K.-G., L.D. (Lukasz Drewniak) and L.D. (Lukasz Dziewit); Investigation, K.P., A.C., P.D., M.D., A.G., G.J., T.K., K.R., M.S. and Z.Y.; Resources, L.D. (Lukasz Drewniak) and L.D. (Lukasz Dziewit); Data Curation, K.P., L.D. (Lukasz Drewniak) and L.D. (Lukasz Dziewit); Writing-Original Draft Preparation, K.P., A.C., P.D., M.D., A.G., G.J., T.K., P.L., K.R., M.S., Z.Y. and L.D. (Lukasz Dziewit); Writing-Review \& Editing, K.P., J.K.-G., L.D. (Lukasz Drewniak) and L.D. (Lukasz Dziewit); Visualization, K.P., P.D., M.D. and M.S.; Supervision, L.D. (Lukasz Drewniak) and L.D. (Lukasz Dziewit); Project Administration, L.D. (Lukasz Drewniak) and L.D. (Lukasz Dziewit); Funding Acquisition, L.D. (Lukasz Drewniak) and L.D. (Lukasz Dziewit).

Funding: This research was funded by the Gekon 2 (Generator of Ecological CONcepts) programme of the National Centre for Research and Development (Poland) and the National Fund for Environmental Protection and Water Management (Poland) [project number GEKON2/O2/266405/7/2015].

Acknowledgments: Library construction and genome assembly were carried out at the DNA Sequencing and Oligonucleotide Synthesis Laboratory of the IBB Polish Academy of Science using the CePT infrastructure financed by the European Union-the European Regional Development Fund [Innovative economy 2007-13, Agreement POIG.02.02.00-14-024/08-00]. We thank Jan Gawor for his technical assistance.

Conflicts of Interest: The authors declare no conflict of interest. The funders had no role in the design of the study; in the collection, analyses, or interpretation of data; in the writing of the manuscript, and in the decision to publish the results.

\section{References}

1. Malla, M.A.; Dubey, A.; Yadav, S.; Kumar, A.; Hashem, A.; Abd_Allah, E.F. Understanding and designing the strategies for the microbe-mediated remediation of environmental contaminants using omics approaches. Front. Microbiol. 2018, 9, 1132. [CrossRef] [PubMed]

2. Danilovich, M.E.; Sanchez, L.A.; Acosta, F.; Delgado, O.D. Antarctic bioprospecting: In pursuit of microorganisms producing new antimicrobials and enzymes. Polar Biol. 2018, 1-17. [CrossRef]

3. Head, I.M.; Jones, D.M.; Roling, W.F. Marine microorganisms make a meal of oil. Nat. Rev. Microbiol. 2006, 4, 173-182. [CrossRef] [PubMed]

4. Harayama, S.; Kasai, Y.; Hara, A. Microbial communities in oil-contaminated seawater. Curr. Opin. Biotechnol. 2004, 15, 205-214. [CrossRef] [PubMed]

5. Sarkar, J.; Kazy, S.K.; Gupta, A.; Dutta, A.; Mohapatra, B.; Roy, A.; Bera, P.; Mitra, A.; Sar, P. Biostimulation of indigenous microbial community for bioremediation of petroleum refinery sludge. Front. Microbiol. 2016, 7, 1407. [CrossRef] [PubMed]

6. Aislabie, J.; Saul, D.J.; Foght, J.M. Bioremediation of hydrocarbon-contaminated polar soils. Extremophiles 2006, 10, 171-179. [CrossRef] [PubMed]

7. Vogt, C.; Richnow, H.H. Bioremediation via in situ microbial degradation of organic pollutants. Adv. Biochem. Eng. Biotechnol. 2014, 142, 123-146. [CrossRef] [PubMed]

8. Piotrowska, M.; Przygodzinska, D.; Matyjewicz, K.; Popowska, M. Occurrence and variety of $\beta$-lactamase genes among Aeromonas spp. isolated from urban wastewater treatment plant. Front. Microbiol. 2017, 8, 863. [CrossRef] [PubMed]

9. Ye, L.; Zhang, T. Pathogenic bacteria in sewage treatment plants as revealed by 454 pyrosequencing. Environ. Sci. Technol. 2011, 45, 7173-7179. [CrossRef] [PubMed]

10. Lood, R.; Erturk, G.; Mattiasson, B. Revisiting antibiotic resistance spreading in wastewater treatment plants-Bacteriophages as a much neglected potential transmission vehicle. Front. Microbiol. 2017, 8, 2298. [CrossRef] [PubMed]

11. Aujoulat, F.; Romano-Bertrand, S.; Masnou, A.; Marchandin, H.; Jumas-Bilak, E. Niches, population structure and genome reduction in Ochrobactrum intermedium: Clues to technology-driven emergence of pathogens. PLoS ONE 2014, 9, e83376. [CrossRef] [PubMed]

12. Kampfer, P.; Huber, B.; Busse, H.J.; Scholz, H.C.; Tomaso, H.; Hotzel, H.; Melzer, F. Ochrobactrum pecoris sp. nov. isolated from farm animals. Int. J. Syst. Evol. Microbiol. 2011, 61, 2278-2283. [CrossRef] [PubMed]

13. Jackel, C.; Hertwig, S.; Scholz, H.C.; Nockler, K.; Reetz, J.; Hammerl, J.A. Prevalence, host range, and comparative genomic analysis of temperate Ochrobactrum phages. Front. Microbiol. 2017, 8, 1207. [CrossRef] [PubMed] 
14. Bathe, S.; Achouak, W.; Hartmann, A.; Heulin, T.; Schloter, M.; Lebuhn, M. Genetic and phenotypic microdiversity of Ochrobactrum spp. FEMS Microbiol. Ecol. 2006, 56, 272-280. [CrossRef] [PubMed]

15. Chain, P.S.; Lang, D.M.; Comerci, D.J.; Malfatti, S.A.; Vergez, L.M.; Shin, M.; Ugalde, R.A.; Garcia, E.; Tolmasky, M.E. Genome of Ochrobactrum anthropi ATCC 49188 T, a versatile opportunistic pathogen and symbiont of several eukaryotic hosts. J. Bacteriol. 2011, 193, 4274-4275. [CrossRef] [PubMed]

16. Menezes, F.G.; Abreu, M.G.; Kawagoe, J.Y.; Warth, A.N.; Deutsch, A.D.; Dornaus, M.F.; Martino, M.D.; Correa, L. Ochrobactrum anthropi bacteremia in a preterm infant with cystic fibrosis. Braz. J. Microbiol. 2014, 45, 559-561. [CrossRef] [PubMed]

17. Moller, L.V.; Arends, J.P.; Harmsen, H.J.; Talens, A.; Terpstra, P.; Slooff, M.J. Ochrobactrum intermedium infection after liver transplantation. J. Clin. Microbiol. 1999, 37, 241-244. [PubMed]

18. Galanakis, E.; Bitsori, M.; Samonis, G.; Christidou, A.; Georgiladakis, A.; Sbyrakis, S.; Tselentis, Y. Ochrobactrum anthropi bacteraemia in immunocompetent children. Scand. J. Infect. Dis. 2002, 34, 800-803. [CrossRef] [PubMed]

19. Aujoulat, F.; Roger, F.; Bourdier, A.; Lotthe, A.; Lamy, B.; Marchandin, H.; Jumas-Bilak, E. From environment to man: Genome evolution and adaptation of human opportunistic bacterial pathogens. Genes 2012, 3, 191-232. [CrossRef] [PubMed]

20. Mahmood, M.S.; Sarwari, A.R.; Khan, M.A.; Sophie, Z.; Khan, E.; Sami, S. Infective endocarditis and septic embolization with Ochrobactrum anthropi: Case report and review of literature. J. Infect. 2000, 40, 287-290. [CrossRef] [PubMed]

21. Zarinviarsagh, M.; Ebrahimipour, G.; Sadeghi, H. Lipase and biosurfactant from Ochrobactrum intermedium strain MZV101 isolated by washing powder for detergent application. Lipids Health Dis. 2017, 16, 177. [CrossRef] [PubMed]

22. Zu, L.; Xiong, J.; Li, G.; Fang, Y.; An, T. Concurrent degradation of tetrabromobisphenol A by Ochrobactrum sp. T under aerobic condition and estrogenic transition during these processes. Ecotoxicol. Environ. Saf. 2014, 104, 220-225. [CrossRef] [PubMed]

23. El-Sayed, W.S.; Ibrahim, M.K.; Abu-Shady, M.; El-Beih, F.; Ohmura, N.; Saiki, H.; Ando, A. Isolation and identification of a novel strain of the genus Ochrobactrum with phenol-degrading activity. J. Biosci. Bioeng. 2003, 96, 310-312. [CrossRef]

24. Zhang, X.-H.; Zhang, G.-S.; Zhang, Z.-H.; Xu, J.-H.; Li, S.-P. Isolation and characterization of a dichlorvos-degrading strain DDV-1 of Ochrobactrum sp. Pedosphere 2006, 16, 64-71. [CrossRef]

25. Ermakova, I.T.; Shushkova, T.V.; Sviridov, A.V.; Zelenkova, N.F.; Vinokurova, N.G.; Baskunov, B.P.; Leontievsky, A.A. Organophosphonates utilization by soil strains of Ochrobactrum anthropi and Achromobacter sp. Arch. Microbiol. 2017, 199, 665-675. [CrossRef] [PubMed]

26. Arulazhagan, P.; Vasudevan, N. Biodegradation of polycyclic aromatic hydrocarbons by a halotolerant bacterial strain Ochrobactrum sp. VA1. Mar. Pollut. Bull. 2011, 62, 388-394. [CrossRef] [PubMed]

27. Gargouri, B.; Karray, F.; Mhiri, N.; Aloui, F.; Sayadi, S. Application of a continuously stirred tank bioreactor (CSTR) for bioremediation of hydrocarbon-rich industrial wastewater effluents. J. Hazard. Mater. 2011, 189, 427-434. [CrossRef] [PubMed]

28. Katsivela, E.; Moore, E.R.; Maroukli, D.; Strompl, C.; Pieper, D.; Kalogerakis, N. Bacterial community dynamics during in-situ bioremediation of petroleum waste sludge in landfarming sites. Biodegradation 2005, 16, 169-180. [CrossRef] [PubMed]

29. Katsivela, E.; Moore, E.R.B.; Kalogerakis, N. Biodegradation of aliphatic and aromatic hydrocarbons: Specificity among bacteria isolated from refinery waste sludge. Water Air Soil Pollut. 2003, 3, 103-115. [CrossRef]

30. Calvo, C.; Silva-Castro, G.A.; Uad, I.; Garcia Fandino, C.; Laguna, J.; Gonzalez-Lopez, J. Efficiency of the EPS emulsifier produced by Ochrobactrum anthropi in different hydrocarbon bioremediation assays. J. Ind. Microbiol. Biotechnol. 2008, 35, 1493-1501. [CrossRef] [PubMed]

31. Sambrook, J.; Russell, D.W. Molecular Cloning: A Laboratory Manual; Cold Spring Harbor Laboratory Press: New York, NY, USA, 2001.

32. Hendricks, C.W.; Doyle, J.D.; Hugley, B. A new solid medium for enumerating cellulose-utilizing bacteria in soil. Appl. Environ. Microbiol. 1995, 61, 2016-2019. [PubMed]

33. Lane, D.J. 16S/23S rRNA sequencing. In Nucleic Acid Techniques in Bacterial Systematics; Stackebrandt, E., Goodfellow, M., Eds.; Wiley: New York, NY, USA, 1991; pp. 115-175. 
34. Martin, M. Cutadapt removes adapter sequences from high-throughput sequencing reads. EMBnet J. 2011, 17, 10. [CrossRef]

35. Aziz, R.K.; Bartels, D.; Best, A.A.; DeJongh, M.; Disz, T.; Edwards, R.A.; Formsma, K.; Gerdes, S.; Glass, E.M.; Kubal, M.; et al. The RAST Server: Rapid annotations using subsystems technology. BMC Genom. 2008, 9, 75. [CrossRef] [PubMed]

36. Wattam, A.R.; Davis, J.J.; Assaf, R.; Boisvert, S.; Brettin, T.; Bun, C.; Conrad, N.; Dietrich, E.M.; Disz, T.; Gabbard, J.L.; et al. Improvements to PATRIC, the all-bacterial Bioinformatics Database and Analysis Resource Center. Nucleic Acids Res. 2017, 45, D535-D542. [CrossRef] [PubMed]

37. Altschul, S.F.; Madden, T.L.; Schaffer, A.A.; Zhang, J.; Zhang, Z.; Miller, W.; Lipman, D.J. Gapped BLAST and PSI-BLAST: A new generation of protein database search programs. Nucleic Acids Res. 1997, 25, 3389-3402. [CrossRef] [PubMed]

38. Finn, R.D.; Bateman, A.; Clements, J.; Coggill, P.; Eberhardt, R.Y.; Eddy, S.R.; Heger, A.; Hetherington, K.; Holm, L.; Mistry, J.; et al. Pfam: The protein families database. Nucleic Acids Res. 2014, 42, D222-D230. [CrossRef] [PubMed]

39. Kanehisa, M.; Furumichi, M.; Tanabe, M.; Sato, Y.; Morishima, K. KEGG: New perspectives on genomes, pathways, diseases and drugs. Nucleic Acids Res. 2017, 45, D353-D361. [CrossRef] [PubMed]

40. Tatusov, R.L.; Fedorova, N.D.; Jackson, J.D.; Jacobs, A.R.; Kiryutin, B.; Koonin, E.V.; Krylov, D.M.; Mazumder, R.; Mekhedov, S.L.; Nikolskaya, A.N.; et al. The COG database: An updated version includes eukaryotes. BMC Bioinform. 2003, 4, 41. [CrossRef] [PubMed]

41. Nawrocki, E.P.; Burge, S.W.; Bateman, A.; Daub, J.; Eberhardt, R.Y.; Eddy, S.R.; Floden, E.W.; Gardner, P.P.; Jones, T.A.; Tate, J.; et al. Rfam 12.0: Updates to the RNA families database. Nucleic Acids Res. 2014, 43, D130-D137. [CrossRef] [PubMed]

42. Lowe, T.M.; Chan, P.P. tRNAscan-SE On-line: Integrating search and context for analysis of transfer RNA genes. Nucleic Acids Res. 2016, 44, W54-W57. [CrossRef] [PubMed]

43. Laslett, D.; Canback, B. ARAGORN, a program to detect tRNA genes and tmRNA genes in nucleotide sequences. Nucleic Acids Res. 2004, 32, 11-16. [CrossRef] [PubMed]

44. Pal, C.; Bengtsson-Palme, J.; Rensing, C.; Kristiansson, E.; Larsson, D.G. BacMet: Antibacterial biocide and metal resistance genes database. Nucleic Acids Res. 2014, 42, D737-D743. [CrossRef] [PubMed]

45. Jia, B.; Raphenya, A.R.; Alcock, B.; Waglechner, N.; Guo, P.; Tsang, K.K.; Lago, B.A.; Dave, B.M.; Pereira, S.; Sharma, A.N.; et al. CARD 2017: Expansion and model-centric curation of the comprehensive antibiotic resistance database. Nucleic Acids Res. 2017, 45, D566-D573. [CrossRef] [PubMed]

46. Chen, L.; Zheng, D.; Liu, B.; Yang, J.; Jin, Q. VFDB 2016: Hierarchical and refined dataset for big data analysis-10 years on. Nucleic Acids Res. 2016, 44, D694-D697. [CrossRef] [PubMed]

47. Eaton, A.D.; Clesceri, L.S.; Greenberg, A.E.; Franson, M.A.H. Standard Methods for the Examination of Water and Wastewater; American Public Health Association (APHA): Washington, DC, USA, 1998.

48. European Committee on Antimicrobial Susceptibility Testing (EUCAST). Available online: http://www. eucast.org (accessed on 13 May 2018).

49. Dziewit, L.; Pyzik, A.; Matlakowska, R.; Baj, J.; Szuplewska, M.; Bartosik, D. Characterization of Halomonas sp. ZM3 isolated from the Zelazny Most post-flotation waste reservoir, with a special focus on its mobile DNA. BMC Microbiol. 2013, 13, 59. [CrossRef] [PubMed]

50. Nieto, J.J.; Ventosa, A.; Ruiz-Berraquero, F. Susceptibility of halobacteria to heavy metals. Appl. Environ. Microbiol. 1987, 53, 1199-1202. [PubMed]

51. Nies, D.H. Microbial heavy-metal resistance. Appl. Microbiol. Biotechnol. 1999, 51, 730-750. [CrossRef] [PubMed]

52. Abou-Shanab, R.A.; van Berkum, P.; Angle, J.S. Heavy metal resistance and genotypic analysis of metal resistance genes in gram-positive and gram-negative bacteria present in Ni-rich serpentine soil and in the rhizosphere of Alyssum murale. Chemosphere 2007, 68, 360-367. [CrossRef] [PubMed]

53. Dib, J.; Motok, J.; Zenoff, V.F.; Ordonez, O.; Farias, M.E. Occurrence of resistance to antibiotics, UV-B, and arsenic in bacteria isolated from extreme environments in high-altitude (above $4400 \mathrm{~m}$ ) Andean wetlands. Curr. Microbiol. 2008, 56, 510-517. [CrossRef] [PubMed]

54. O'Toole, G.A. Microtiter dish biofilm formation assay. J. Vis. Exp. 2011. [CrossRef] [PubMed]

55. Andersson, S.; Kuttuva Rajarao, G.; Land, C.J.; Dalhammar, G. Biofilm formation and interactions of bacterial strains found in wastewater treatment systems. FEMS Microbiol. Lett. 2008, 283, 83-90. [CrossRef] [PubMed] 
56. Deflaun, M.F.; Steffan, R.J. Bioaugmentation. In Encyclopedia of Environmental Microbiology; Bitton, G., Ed.; Wiley-Interscience: New York, NY, USA, 2002; Volume 1, pp. 434-442.

57. Bagi, Z.; Acs, N.; Balint, B.; Horvath, L.; Dobo, K.; Perei, K.R.; Rakhely, G.; Kovacs, K.L. Biotechnological intensification of biogas production. Appl. Microbiol. Biotechnol. 2007, 76, 473-482. [CrossRef] [PubMed]

58. Nielsen, H.B.; Mladenovska, Z.; Ahring, B.K. Bioaugmentation of a two-stage thermophilic $\left(68^{\circ} \mathrm{C} / 55^{\circ} \mathrm{C}\right)$ anaerobic digestion concept for improvement of the methane yield from cattle manure. Biotechnol. Bioeng. 2007, 97, 1638-1643. [CrossRef] [PubMed]

59. Weiss, S.; Tauber, M.; Somitsch, W.; Meincke, R.; Muller, H.; Berg, G.; Guebitz, G.M. Enhancement of biogas production by addition of hemicellulolytic bacteria immobilised on activated zeolite. Water Res. 2010, 44, 1970-1980. [CrossRef] [PubMed]

60. Tsapekos, P.; Kougias, P.G.; Vasileiou, S.A.; Treu, L.; Campanaro, S.; Lyberatos, G.; Angelidaki, I. Bioaugmentation with hydrolytic microbes to improve the anaerobic biodegradability of lignocellulosic agricultural residues. Bioresour. Technol. 2017, 234, 350-359. [CrossRef] [PubMed]

61. Cater, M.; Fanedl, L.; Malovrh, S.; Marinsek Logar, R. Biogas production from brewery spent grain enhanced by bioaugmentation with hydrolytic anaerobic bacteria. Bioresour. Technol. 2015, 186, 261-269. [CrossRef] [PubMed]

62. Fotidis, I.A.; Wang, H.; Fiedel, N.R.; Luo, G.; Karakashev, D.B.; Angelidaki, I. Bioaugmentation as a solution to increase methane production from an ammonia-rich substrate. Environ. Sci. Technol. 2014, 48, 7669-7676. [CrossRef] [PubMed]

63. Poszytek, K.; Ciezkowska, M.; Sklodowska, A.; Drewniak, L. Microbial Consortium with High Cellulolytic Activity (MCHCA) for enhanced biogas production. Front. Microbiol. 2016, 7, 324. [CrossRef] [PubMed]

64. Ariunbaatar, J.; Panico, A.; Esposito, G.; Pirozzi, F.; Lens, P.N.L. Pretreatment methods to enhance anaerobic digestion of organic solid waste. Appl. Energy 2014, 123, 143-156. [CrossRef]

65. Parawira, W.; Tekere, M. Biotechnological strategies to overcome inhibitors in lignocellulose hydrolysates for ethanol production: Review. Crit. Rev. Biotechnol. 2011, 31, 20-31. [CrossRef] [PubMed]

66. Herrero, M.; Stuckey, D.C. Bioaugmentation and its application in wastewater treatment: A review. Chemosphere 2015, 140, 119-128. [CrossRef] [PubMed]

67. Cevallos, M.A.; Cervantes-Rivera, R.; Gutierrez-Rios, R.M. The repABC plasmid family. Plasmid 2008, 60, 19-37. [CrossRef] [PubMed]

68. Textor, S.; Wendisch, V.F.; De Graaf, A.A.; Muller, U.; Linder, M.I.; Linder, D.; Buckel, W. Propionate oxidation in Escherichia coli: Evidence for operation of a methylcitrate cycle in bacteria. Arch. Microbiol. 1997, 168, 428-436. [CrossRef] [PubMed]

69. Lv, P.; Luo, J.; Zhuang, X.; Zhang, D.; Huang, Z.; Bai, Z. Diversity of culturable aerobic denitrifying bacteria in the sediment, water and biofilms in Liangshui River of Beijing, China. Sci. Rep. 2017, 7, 10032. [CrossRef] [PubMed]

70. Tan, T.; Liu, C.; Liu, L.; Zhang, K.; Zou, S.; Hong, J.; Zhang, M. Hydrogen sulfide formation as well as ethanol production in different media by cysND-and/or cysIJ-inactivated mutant strains of Zymomonas mobilis ZM4. Bioprocess. Biosyst. Eng. 2013, 36, 1363-1373. [CrossRef] [PubMed]

71. Ciriminna, R.; Meneguzzo, F.; Delisi, R.; Pagliaro, M. Citric acid: Emerging applications of key biotechnology industrial product. Chem. Cent. J. 2017, 11, 22. [CrossRef] [PubMed]

72. Jormakka, M.; Byrne, B.; Iwata, S. Formate dehydrogenase-A versatile enzyme in changing environments. Curr. Opin. Struct. Biol. 2003, 13, 418-423. [CrossRef]

73. Oleszczuk, P. Phytotoxicity of municipal sewage sludge composts related to physico-chemical properties, PAHs and heavy metals. Ecotoxicol. Environ. Saf. 2008, 69, 496-505. [CrossRef] [PubMed]

74. Werle, S.; Wilk, R.K. A review of methods for the thermal utilization of sewage sludge: The Polish perspective. Renew. Energy 2010, 35, 1914-1919. [CrossRef]

75. Cieslik, B.M.; Namiesnik, J.; Konieczka, P. Review of sewage sludge management: Standards, regulations and analytical methods. J. Clean. Prod. 2015, 90, 1-15. [CrossRef]

76. Dixit, R.; Malaviya, D.; Pandiyan, K.; Singh, B.U.; Sahu, A.; Shukla, R.; Singh, P.B.; Rai, P.J.; Sharma, K.P.; Lade, H.; et al. Bioremediation of heavy metals from soil and aquatic environment: An overview of principles and criteria of fundamental processes. Sustainability 2015, 7, 2189-2212. [CrossRef]

77. Binet, M.R.; Poole, R.K. Cd(II), $\mathrm{Pb}(\mathrm{II})$ and $\mathrm{Zn}$ (II) ions regulate expression of the metal-transporting P-type ATPase ZntA in Escherichia coli. FEBS Lett. 2000, 473, 67-70. [CrossRef] 
78. Hou, Z.; Mitra, B. The metal specificity and selectivity of ZntA from Escherichia coli using the acylphosphate intermediate. J. Biol. Chem. 2003, 278, 28455-28461. [CrossRef] [PubMed]

79. Hou, Z.J.; Narindrasorasak, S.; Bhushan, B.; Sarkar, B.; Mitra, B. Functional analysis of chimeric proteins of the Wilson $\mathrm{Cu}(\mathrm{I})$-ATPase (ATP7B) and ZntA, a $\mathrm{Pb}(\mathrm{II}) / \mathrm{Zn}(\mathrm{II}) / \mathrm{Cd}(\mathrm{II})$-ATPase from Escherichia coli. J. Biol. Chem. 2001, 276, 40858-40863. [CrossRef] [PubMed]

80. Alvarez, A.H.; Moreno-Sanchez, R.; Cervantes, C. Chromate efflux by means of the ChrA chromate resistance protein from Pseudomonas aeruginosa. J. Bacteriol. 1999, 181, 7398-7400. [PubMed]

81. Anton, A.; Grosse, C.; Reissmann, J.; Pribyl, T.; Nies, D.H. CzcD is a heavy metal ion transporter involved in regulation of heavy metal resistance in Ralstonia sp. strain CH34. J. Bacteriol. 1999, 181, 6876-6881. [PubMed]

82. Munkelt, D.; Grass, G.; Nies, D.H. The chromosomally encoded cation diffusion facilitator proteins DmeF and FieF from Wautersia metallidurans CH34 are transporters of broad metal specificity. J. Bacteriol. 2004, 186, 8036-8043. [CrossRef] [PubMed]

83. Ryan, D.; Colleran, E. Arsenical resistance in the IncHI2 plasmids. Plasmid 2002, 47, 234-240. [CrossRef]

84. Rizzo, L.; Manaia, C.; Merlin, C.; Schwartz, T.; Dagot, C.; Ploy, M.C.; Michael, I.; Fatta-Kassinos, D. Urban wastewater treatment plants as hotspots for antibiotic resistant bacteria and genes spread into the environment: A review. Sci. Total Environ. 2013, 447, 345-360. [CrossRef] [PubMed]

85. Nadjar, D.; Labia, R.; Cerceau, C.; Bizet, C.; Philippon, A.; Arlet, G. Molecular characterization of chromosomal class $\mathrm{C}$ beta-lactamase and its regulatory gene in Ochrobactrum anthropi. Antimicrob. Agents Chemother. 2001, 45, 2324-2330. [CrossRef] [PubMed]

86. Kadlec, K.; Kehrenberg, C.; Schwarz, S. Efflux-mediated resistance to florfenicol and/or chloramphenicol in Bordetella bronchiseptica: Identification of a novel chloramphenicol exporter. J. Antimicrob. Chemother. 2007, 59, 191-196. [CrossRef] [PubMed]

87. Pradel, E.; Pages, J.M. The AcrAB-TolC efflux pump contributes to multidrug resistance in the nosocomial pathogen Enterobacter aerogenes. Antimicrob. Agents Chemother. 2002, 46, 2640-2643. [CrossRef] [PubMed]

88. Natale, P.; Bruser, T.; Driessen, A.J. Sec- and Tat-mediated protein secretion across the bacterial cytoplasmic membrane-distinct translocases and mechanisms. Biochim. Biophys. Acta 2008, 1778, 1735-1756. [CrossRef] [PubMed]

89. Nuccio, S.P.; Baumler, A.J. Evolution of the chaperone/usher assembly pathway: Fimbrial classification goes Greek. Microbiol. Mol. Biol. Rev. 2007, 71, 551-575. [CrossRef] [PubMed]

90. Wang, X.; Quinn, P.J.; Yan, A. Kdo2-lipid A: Structural diversity and impact on immunopharmacology. Biol. Rev. Camb. Philos. Soc. 2015, 90, 408-427. [CrossRef] [PubMed]

91. Polissi, A.; Sperandeo, P. The lipopolysaccharide export pathway in Escherichia coli: Structure, organization and regulated assembly of the Lpt machinery. Mar. Drugs 2014, 12, 1023-1042. [CrossRef] [PubMed]

92. Manning, P.A.; Stroeher, U.H.; Karageorgos, L.E.; Morona, R. Putative O-antigen transport genes within the $r f b$ region of Vibrio cholerae $\mathrm{O} 1$ are homologous to those for capsule transport. Gene 1995, 158, 1-7. [CrossRef]

93. Marczak, M.; Mazur, A.; Koper, P.; Zebracki, K.; Skorupska, A. Synthesis of rhizobial exopolysaccharides and their importance for symbiosis with legume plants. Genes 2017, 8, 360. [CrossRef] [PubMed]

94. Davey, M.E.; O'Toole, G.A. Microbial biofilms: From ecology to molecular genetics. Microbiol. Mol. Biol. Rev. 2000, 64, 847-867. [CrossRef] [PubMed]

95. Loupasaki, E.; Diamadopoulos, E. Attached growth systems for wastewater treatment in small and rural communities: A review. J. Chem. Technol. Biotechnol. 2013, 88, 190-204. [CrossRef]

(c) 2018 by the authors. Licensee MDPI, Basel, Switzerland. This article is an open access article distributed under the terms and conditions of the Creative Commons Attribution (CC BY) license (http:/ / creativecommons.org/licenses/by/4.0/). 